DOI: $10.15193 /$ zntj/2018/114/222

\author{
MONIKA TRZĄSKOWSKA, ANITA TRZCIŃSKA, ŻANETA KAPICA
}

\title{
JAKOŚĆ SENSORYCZNA I PRZEŻYWALNOŚĆ POTENCJALNIE PROBIOTYCZNYCH SZCZEPÓW LACTOBACILLUS W FERMENTOWANYM NAPOJU MIODOWYM
}

\begin{abstract}
Streszczenie
Celem pracy było określenie możliwości zastosowania bakterii potencjalnie probiotycznych Lactobacillus johnsonii K4 lub Lactobacillus casei $\mathrm{O} 12$ do produkcji napoju miodowego akceptowanego sensorycznie i zawierającego żywe mikroorganizmy. Materiałem do badań były napoje miodowe przygotowane z miodu wielokwiatowego i wody wodociągowej (12,05 g/100 ml). Napoje poddano 2-, 3-, 4- i 5-dniowej fermentacji monokulturą bakterii (po inokulacji ok. $7 \log$ jtk $/ \mathrm{cm}^{3}$ ) w temp. 30 i $37{ }^{\circ} \mathrm{C}$. Średnia liczb bakterii po fermentacji zawierała się w przedziale $6,75 \div 8,14 \log \mathrm{jtk} / \mathrm{cm}^{3}$. Wzrost bakterii był zależny od szczepu, czasu i temperatury fermentacji $(\mathrm{p}<0,05)$. Te same czynniki istotnie wpłynęły na średnie wartości $\mathrm{pH}$ we wszystkich próbach w kolejnych dniach fermentacji i mieściły się w granicach $4,6 \div 4.8$ $(\mathrm{p}<0,05)$. Czas fermentacji był czynnikiem statystycznie istotnie wpływającym na ocenę sensoryczną $(\mathrm{p}<0,05)$. Najwyższe noty w ocenie sensorycznej przyznano próbkom fermentowanym szczepem $L b$. casei $\mathrm{O} 12$ przez 2 dni w temp. $37^{\circ} \mathrm{C}$. Wybrane bakterie z rodzaju Lactobacillus można zastosować do wytwarzania innowacyjnego napoju o pożądanych cechach sensorycznych. Na tym etapie badań produkt nie może być nazwany probiotycznym, jednak jakość sensoryczna i zakres przeżywalności szczepów predysponuje do dalszej oceny ich właściwości probiotycznych.
\end{abstract}

Słowa kluczowe: napój miodowy, probiotyk, fermentacja, Lactobacillus

\section{Wprowadzenie}

Dążeniem nowoczesnego konsumenta jest poprawa jakości życia, m.in. przez odpowiednio skomponowaną dietę, która umożliwi długotrwałe utrzymanie organizmu w dobrym zdrowiu i sprawności fizycznej. Poprawa świadomości dotyczącej zdrowego trybu życia, jak również naukowo udowodniony wpływ diety na prewencję i łagodze-

Dr inż. M. Trzaskowska, mgr inż. A. Trzcińska, mgr inż. Ż. Kapica, Katedra Technologii Gastronomicznej i Higieny Żywności, Wydz. Nauk o Żywieniu Człowieka i Konsumpcji, Szkoła Główna Gospodarstwa Wiejskiego w Warszawie, ul. Nowoursynowska 159 C, 02-776 Warszawa.

Kontakt: monika_trzaskowska@sggw.pl 
nie dolegliwości wielu chorób, wpłynęły na wyodrębnienie oddzielnej kategorii żywności nazwanej żywnością funkcjonalną $[11,16]$. Do tej grupy zalicza się produkty spożywcze wzbogacone w probiotyki, które definiuje się jako żywe mikroorganizmy, które po podaniu w odpowiednich ilościach przynoszą korzyści zdrowotne gospodarzowi [5].

Miodem nazywa się słodką substancję, produkowaną przez pszczoły Apis mellife$r a \mathrm{z}$ wydzielin żywych części roślin, nektaru kwiatowego lub wydzielin owadów wysysających żywe części roślin, które pszczoły zbierają, przerabiają, łączą z wydzielinami swoich gruczołów, odwadniają, magazynują i pozostawiają do dojrzewania w plastrach [4]. Miód dostarcza cennych składników budulcowych, energetycznych oraz regulujących i dzięki temu poprawia zarówno psychiczną, jak i fizyczną kondycję spożywających go osób. Wykazuje również działanie terapeutyczne i profilaktyczne w wielu schorzeniach [14].

Rynek napojów funkcjonalnych jest rozwijającym się sektorem przemysłu spożywczego. Poza produkcją tradycyjnych napojów prowadzi się innowacyjne badania mające na celu rozwój probiotycznych fermentowanych napojów bezmlecznych z różnych substratów, w tym mleka sojowego, serwatki, zbóż, soków warzywnych i owocowych [15].

Wyróżnia się trzy grupy kryteriów uwzględnianych podczas poszukiwania szczepów probiotycznych: (i) wymagania ogólne, np. pochodzenie, bezpieczeństwo; (ii) wymagania technologiczne, np. wzrost i przeżywalność w produkcie; (iii) działanie dobroczynne [8].

Celem pracy było określenie możliwości zastosowania bakterii potencjalnie probiotycznych Lactobacillus johnsonii K4 lub Lactobacillus casei O12 do produkcji napoju miodowego akceptowanego sensorycznie i zawierającego żywe mikroorganizmy.

\section{Material i metody badań}

Materiałem do badań był napój miodowy przygotowany samodzielnie z miodu wielokwiatowego i wody wodociągowej. Miód zakupiono w jednym z lokalnych sklepów. Zgodnie $\mathrm{z}$ deklaracją producenta była to mieszanka miodów pochodząca z pasiek państw członkowskich Unii Europejskiej, jak i z pasiek nieeuropejskich. Miód był konfekcjonowany przez firmę „HUZAR” Sp. z o.o. pod marką „Złota Pasieka”, specjalnie dla sieci sklepów Biedronka (Jeronimo Martins Polska S.A.).

Do badań wykorzystano dwa potencjalnie probiotyczne szczepy fermentacji mlekowej - Lb. casei O12, wyizolowany z ukwaszonych ogórków i Lb. johnsonii K4, wyizolowany z kiszonej kapusty [19].

Do badań przygotowano 8 wariantów napoju miodowego, które różniły się dodanym szczepem bakterii, temperaturą i czasem fermentacji. Napój miodowy bez dodatku bakterii stanowił próbę kontrolną. 
Wodę wodociągową doprowadzano do wrzenia, po czym przelewano do sterylnych słoi i studzono do temperatury ok. $40^{\circ} \mathrm{C}$. Następnie rozpuszczano w niej miód, aby stężenie sacharydów wynosiło $10 \%, \mathrm{tj} .12,05 \mathrm{~g}$ miodu w $100 \mathrm{~cm}^{3}$ wody.

Kultury macierzyste (Lb. casei O12 i Lb. johnsonii K4) przechowywano w stanie zamrożonym w temp. $-80{ }^{\circ} \mathrm{C}$ w 20 -procentowym glicerolu $(\mathrm{m} / \mathrm{v})$. Oczko ezy rozmrożonej kultury macierzystej przenoszono do $5 \mathrm{ml}$ bulionu MRS (Merck, Polska), inkubowano $24 \mathrm{~h}$ w temp. $37{ }^{\circ} \mathrm{C}$. Następnie $1 \mathrm{~cm}^{3}$ uzyskanej hodowli przenoszono do $9 \mathrm{~cm}^{3}$ bulionu MRS i inkubowano kolejne $24 \mathrm{~h} \mathrm{w}$ temp. $37^{\circ} \mathrm{C}$. W wyniku tej procedury uzyskano liczbę bakterii na poziomie $8 \div 9 \log \mathrm{jtk} / \mathrm{cm}^{3}$. Uzyskaną hodowlę wirowano 5 min przy $1000 \mathrm{obr} . / \mathrm{min}$. Po usunięciu supernatantu do probówki dodawano $10 \mathrm{~cm}^{3}$ jałowej wody. Do $100 \mathrm{~cm}^{3}$ napoju miodowego dodawano niezwłocznie $1 \mathrm{~cm}^{3}$ monokultury i uzyskiwano liczbę bakterii na poziomie średnio 7,02 $\log \mathrm{jtk} / \mathrm{cm}^{3}$. Mieszaninę poddawano 2-, 3-, 4- i 5-dniowej fermentacji w temp. 30 i $37^{\circ} \mathrm{C}$. Fermentację wykonywano w dwóch wariantach: w pierwszym napój miodowy fermentowano 2 i 4 dni, w drugim - 3 i 5 dni.

Po fermentacji określano liczbę bakterii, mierzono poziom $\mathrm{pH}$ oraz przeprowadzano ocenę sensoryczną napojów. Proces fermentacji wykonano w trzech powtórzeniach.

Liczbę bakterii fermentacji mlekowej oznaczano metodą płytkową, wgłębną. W dniu posiewu fermentowany napój miodowy mieszano przez $2 \mathrm{~min}$, pobierano $1 \mathrm{~cm}^{3}$ i dodawano do $9 \mathrm{~cm}^{3}$ sterylnej wody peptonowej (Biokar, Polska). Wykonywano szereg rozcieńczeń dziesiętnych od $10^{-1}$ do $10^{-6}$. Następnie z rozcieńczenia $10^{-5}$ i $10^{-6}$ przenoszono po $0,1 \mathrm{~cm}^{3}$ zawiesiny na płytki Petriego (w dwóch powtórzeniach), zalewano agarem MRS (Merck, Niemcy) i dokładnie mieszano. Po zestaleniu się pożywki płytki inkubowano w temp. $37^{\circ} \mathrm{C}$ przez $48 \mathrm{~h}$ i liczono typowe kolonie.

Pomiar $\mathrm{pH}$ wykonywano po 3 i 5 dniach fermentacji. Przed pomiarem próby pozostawiano w temp. $20 \pm 2{ }^{\circ} \mathrm{C}$, aby wyrównać różnice temperaturowe podczas fermentacji. Pomiar pH wykonywano metodą potencjometryczną za pomocą aparatu Elmetron CP501 (Elmetron Sp.j., Polska).

Do przeprowadzenia semikonsumenckiej analizy sensorycznej wykorzystano 9-stopniową skalę hedoniczną. Zadanie oceniającego polegało na wpisaniu kodu próbki w odpowiednim miejscu na karcie odpowiedzi, spróbowaniu napoju miodowego i przyporządkowaniu mu jednego z dziewięciu określeń podanych na karcie, zgodnie z wrażeniem sensorycznym, jakie wywołała oceniania próbka. Określenia były następujące: 1 - wyjątkowo niepożądana, 2 - bardzo niepożądana, 3 - niepożądana, 4 nieco niepożądana, 5 - ani pożądana, ani niepożądana, 6 - nieco pożądana, 7 - pożądana, 8 - bardzo pożądana, 9 - wyjątkowo pożądana. Osobami oceniającymi byli studenci oraz pracownicy Szkoły Główniej Gospodarstwa Wiejskiego w Warszawie. Ocena była przeprowadzana bezpośrednio po procesie fermentacji, przy czym po fer- 
mentacji 2-dniowej wykonano 50 ocen, po 3-dniowej - 30 ocen, a po 4-dniowej - 53 oceny. Próby po 5-dniowej fermentacji nie były poddawane ocenie ze względu na dyskwalifikujący zapach napojów.

Analizę statystyczną wyników wykonano w programie Statistica 12.0. Obliczono wartości średnie, odchylenia standardowe i zastosowano test $t$-dla prób niezależnych i wieloczynnikową analizę wariancji ANOVA. Do porównania średnich post-hoc wykorzystano test Bonferroniego. Różnicę uznawano za statystycznie istotną przy $\mathrm{p}<0,05$.

\section{Wyniki i dyskusja}

Zgodnie z definicją probiotyków [5] ich korzystny wpływ na zdrowie człowieka wymaga stosowania go w określonej liczbie. Działanie probiotyczne jest związane ze szczepem i efektami zdrowotnymi (poszczególne efekty mogą wymagać różnej liczby probiotyku). Jednocześnie wiadomo, że to nie może być mała dawka mikroorganizmów [1]. Do tej pory podjęto kilka prób zdefiniowania tej dawki i pierwsze wytyczne były określane na poziomie $6 \div 8 \log \mathrm{jtk} / \mathrm{g}$ produktu w czasie konsumpcji. Odpowiada to dawce $8 \div 10 \log$ jtk/100 g produktu [10]. Wielkość dawki zależy jednak od szczepu probiotycznego i możliwa jest do ustalenia wyłącznie na podstawie badań klinicznych [17].

Zielińska i wsp. [19] potwierdzają, że szczepy wyizolowane z produktów fermentowanych, takich jak kiszona kapusta (Lb. johnsonii K4) lub ogórki (Lb. casei O12) są zdolne do przeżywania $\mathrm{w}$ warunkach panujących $\mathrm{w}$ przewodzie pokarmowym oraz adhezji do ściany jelita. Właściwości te pozwalają zaliczyć szczepy do potencjalnych probiotyków.

Po fermentacji napoju miodowego średnia liczba bakterii była zróżnicowana w zależności od szczepu oraz czasu i temperatury fermentacji. W napoju fermentowanym $L b$. casei $\mathrm{O} 12$ największą liczbę bakterii $\left(8,14 \log \mathrm{jtk} / \mathrm{cm}^{3}\right)$ stwierdzono po 3 dniach procesu w temp. $30^{\circ} \mathrm{C}$. Natomiast fermentacja w $37^{\circ} \mathrm{C}$ skutkowała maksymalnym stężeniem tych bakterii już po 2 dobach i wynosiła $7,56 \log \mathrm{jtk} / \mathrm{cm}^{3}$. W kolejnych dniach procesu obserwowano jednak zamieranie tych mikroorganizmów. Podczas fermentacji napoju miodowego szczepem $L b$. johnsonii $\mathrm{K} 4 \mathrm{w}$ temp. $30{ }^{\circ} \mathrm{C}$, największą liczbę komórek, tj. 7,80 log jtk/ $\mathrm{cm}^{3}$ stwierdzono po 2 dniach procesu. Podwyższenie temperatury fermentacji do $37{ }^{\circ} \mathrm{C}$ skutkowało maksymalnym stężeniem komórek, tj. $7,73 \log \mathrm{jtk} / \mathrm{cm}^{3}$ po 5 dniach procesu (rys. 1A i 1B). Zatem porcja $100 \mathrm{ml}$ tego napoju dostarczałaby ok. $10 \log$ jtk żywych bakterii i spełniała kryterium wymaganej liczby bakterii w żywności probiotycznej [6]. 
A

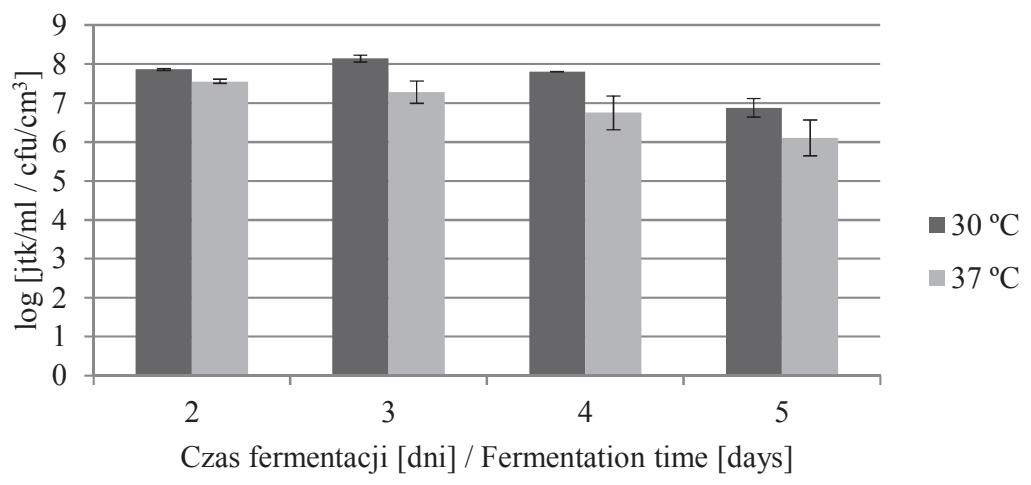

$\mathrm{B}$

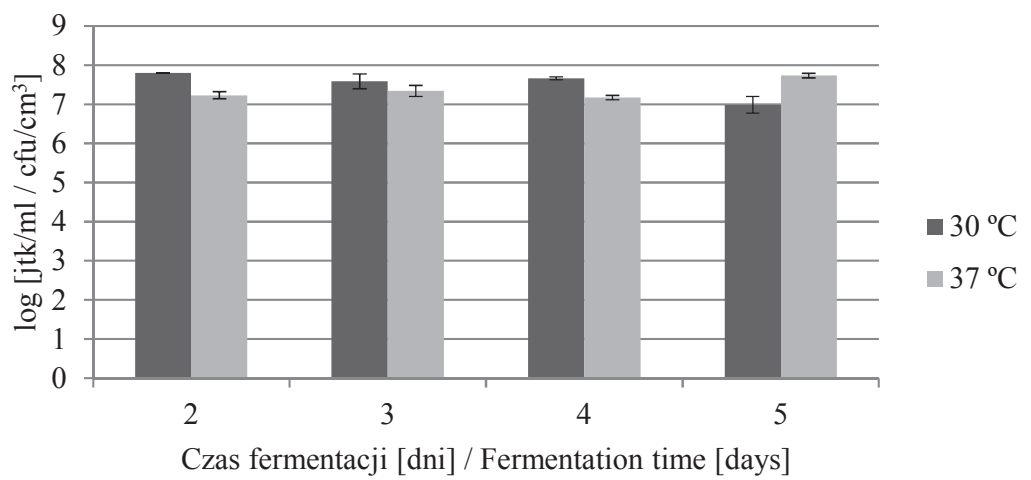

Objaśnienia / Explanatory notes:

Słupki oznaczają średnią liczbę bakterii, odcinki oznaczają odchylenia standardowe; $n=3$ / Bars indicate mean count of bacteria, line segments indicate standard deviations; $\mathrm{n}=3$.

Rys. 1. Średnia liczba bakterii Lb. casei O12 (A) i Lb. johnsonii K4 (B) w napojach miodowych fermentowanych w temp. 30 lub $37^{\circ} \mathrm{C}$

Fig. 1. Mean number of Lb. casei $\mathrm{O} 12$ (A) and Lb. johnsonii $\mathrm{K} 4$ (B) in honey beverages fermented at 30 or $37^{\circ} \mathrm{C}$

Największą liczbę bakterii stwierdzono w napoju fermentowanym 3 dni w temp. $30{ }^{\circ} \mathrm{C}$ przez szczep $L b$. casei $\mathrm{O} 12$. Najmniej tych bakterii było natomiast w produkcie fermentowanym przez $5 \mathrm{dni}$ w temp. $37^{\circ} \mathrm{C}$, także przez szczep Lb. casei O12. Zaobserwowany wzrost i przeżywalność badanych szczepów Lactobacillus spełnia kryterium technologiczne stawiane probiotykom. 
$\mathrm{Na}$ podstawie analizy wariancji wykazano, że na liczbę bakterii wpływ miały temperatura i czas fermentacji oraz zastosowany szczep bakterii $(\mathrm{p}<0,05)$. Porównanie średnich post-hoc za pomocą testu Bonferroniego ujawniło, że statystycznie istotnie mniej bakterii było w próbkach fermentowanych 5 dni. Statystycznie istotne obniżenie liczby bakterii $L$ b. casei $\mathrm{O} 12$ stwierdzano po fermentacji prób w temp. $37{ }^{\circ} \mathrm{C}$ oraz po przedłużeniu czasu procesu do 4 i 5 dni. Natomiast podczas fermentacji napoju miodowego szczepem $L b$. johnsonii $\mathrm{K} 4 \mathrm{w}$ temp. $37^{\circ} \mathrm{C}$ i 5-dniowy czas fermentacji były czynnikami ograniczającymi rozwój bakterii $(\mathrm{p}<0,05)$.

Wartość pH wszystkich prób poddanych fermentacji obniżyła się statystycznie istotnie w porównaniu z próbą kontrolną $(\mathrm{p}<0,05)$. Średnia wartość $\mathrm{pH}$ we wszystkich próbach w kolejnych dniach fermentacji mieściła się w granicach 4,6 4,8 (tab. 1).

Obniżenie wartości $\mathrm{pH}$ w produktach poddanych fermentacji mlekowej jest naturalnym zjawiskiem, które odnotowano także w innych badaniach. Kun i wsp. [12] fermentowali różnymi szczepami z rodzaju Bifidobacterium sok marchwiowy, w którym nastąpiło obniżenie wartości pH z 6,4 do 4,5. Szydłowska i Kołożyn-Krajewska [18] prowadziły badania przecierów z dyni i wykazały, że w zależności od czasu i temperatury fermentacji, użytego szczepu i dodatku inuliny wartość $\mathrm{pH}$ w tym produkcie zmniejszyła się o $1,79 \div 2,12$ jednostki. Łapińska [13] w fermentowanym napoju miodowym również zaobserwowała obniżenie $\mathrm{pH}$. Średnia wartość $\mathrm{pH}$ wszystkich prób napojów miodowych fermentowanych bakteriami fermentacji mlekowej obniżyła się z 6,2 do ok. 3,65 . Istotny wpływ na wartość $\mathrm{pH}$ miało stężenie cukru i zastosowany szczep podczas procesu fermentacji $(\mathrm{p}<0,05)$.

Tabela 1. Wartość pH fermentowanych napojów w zależności od temperatury i czasu fermentacji Table 1. $\mathrm{pH}$ value of fermented beverages depending on temperature and fermentation time

\begin{tabular}{||c|c|c|c|c||}
\hline \multirow{2}{*}{$\begin{array}{c}\text { Szczep } \\
\text { Strain }\end{array}$} & $\begin{array}{c}\text { Temperatura } \\
\text { fermentacji }\end{array}$ & Próba kontrolna & \multicolumn{2}{|c|}{$\begin{array}{c}\text { Czas fermentacji [dni] } \\
\text { Fermentation time [days] }\end{array}$} \\
\cline { 4 - 5 } & $\begin{array}{c}\text { Fermentation } \\
\text { temperature }\left[{ }^{\circ} \mathrm{C}\right]\end{array}$ & Control sample & 3 & 5 \\
\hline \multirow{2}{*}{ Lb. casei $\mathrm{O} 12$} & 30 & $6,70^{\mathrm{a}} \pm 0,10$ & $4,90^{\mathrm{Ab}} \pm 0,15$ & $4,80^{\mathrm{Ab}} \pm 0,15$ \\
\cline { 2 - 5 } & 37 & $6,60^{\mathrm{a}} \pm 0,12$ & $4,70^{\mathrm{Ab}} \pm 0,10$ & $4,50^{\mathrm{Ab}} \pm 0,10$ \\
\hline \multirow{2}{*}{ Lb. johnsonii $\mathrm{K} 4$} & 30 & $6,70^{\mathrm{a}} \pm 0,15$ & $4,70^{\mathrm{A}, \mathrm{b}} \pm 0,15$ & $4,70^{\mathrm{Ab}} \pm 0,10$ \\
\cline { 2 - 5 } & 37 & $6,60^{\mathrm{a}} \pm 0,10$ & $4,60^{\mathrm{Ab}} \pm 0,15$ & $4,70^{\mathrm{Ab}} \pm 0,15$ \\
\hline
\end{tabular}

Objaśnienia / Explanatory notes:

$\mathrm{a}, \mathrm{b}$ - wartości średnie oznaczone różnymi literami (małymi w rzędach, dużymi w kolumnach) różną się statystycznie istotnie $(\mathrm{p}<0,05)$ / mean values denoted by different letters (lowercase in rows, uppercase in columns) differ statistically significantly $(\mathrm{p}<0.05) ; \mathrm{n}=3$.

Ocena semikonsumencka przeprowadzana jest w celu określenia upodobań konsumentów i sprawdzenia stopnia pożądalności produktów poddawanych ocenie. Prefe- 
rencje konsumentów uzależnione są od atrakcyjności sensorycznej, wartości odżywczej oraz bezpieczeństwa stosowania wybieranych produktów [2, 3].

Ocenie semikonsumenckiej poddano tylko próby napojów miodowych otrzymanych po 2, 3 i 4 dniach fermentacji. W napojach miodowych po 5-dniowej fermentacji stwierdzono dyskwalifikujące cechy sensoryczne.

$\mathrm{Na}$ podstawie analizy wariancji wykazano, że spośród trzech czynników (tj. szczepu, temperatury i czasu fermentacji) na wynik oceny sensorycznej istotny wpływ miał czas fermentacji $(\mathrm{p}<0,05)$. Dodatkowo istotna była interakcja szczep $\times$ temperatura oraz temperatura $\times$ czas fermentacji. Oznacza to, że pożądalność produktów fermentowanych w obrębie jednego szczepu jest warunkowana temperaturą fermentacji. Natomiast efekt główny ,temperatura” był warunkowany czasem fermentacji. W uzyskanych danych stwierdzono zmianę wpływu temperatury na pożądalność. Po 2 dniach fermentacji wyżej oceniono produkty fermentowane w temp. $37^{\circ} \mathrm{C}$. Wydłużenie fermentacji o kolejne dni spowodowało zmianę, tj. wyższą ocenę sensoryczną przypisano produktom fermentowanym $\mathrm{w}$ temp. $30^{\circ} \mathrm{C}$. Porównanie średnich post-hoc za pomocą testu Bonferroniego dowiodło, że statystycznie istotnie wyżej ocenione zostały próby fermentowane w ciągu 2 dni przez $L$ b. casei $\mathrm{O} 12 \mathrm{w}$ temp. $37^{\circ} \mathrm{C}$. Statystycznie istotnie niżej ocenione były próby fermentowane w ciągu 3 i 4 dni przez Lb. johnsonii $\mathrm{K} 4$ w temp. $37^{\circ} \mathrm{C}$ oraz przez Lb. casei $\mathrm{O} 12 \mathrm{w}$ temp. $30^{\circ} \mathrm{C}$ przez 3 dni $(\mathrm{p}<0,05)-$ tab. 2.

Tabela 2. Średnie wyniki oceny semikonsumenckiej fermentowanych napojów w zależności od temperatury i czasu fermentacji

Table 2. Mean results of semi-consumer evaluation of fermented beverages depending on temperature and fermentation time

\begin{tabular}{|c|c|c|c|c|}
\hline \multirow{2}{*}{$\begin{array}{c}\text { Szczep } \\
\text { Strain }\end{array}$} & \multirow{2}{*}{$\begin{array}{c}\text { Temperatura fermentacji } \\
\text { Fermentation temperature } \\
{\left[{ }^{\circ} \mathrm{C}\right]}\end{array}$} & \multicolumn{3}{|c|}{$\begin{array}{c}\text { Czas fermentacji [dni] } \\
\text { Fermentation time [days] }\end{array}$} \\
\hline & & 2 & 3 & 4 \\
\hline \multirow{2}{*}{ Lb. casei $\mathrm{O} 12$} & 30 & $5,24 \pm 2,10$ & $4,27 \pm 2,36$ & $5,06^{*} \pm 2,60^{*}$ \\
\hline & 37 & $5,96^{*} \pm 1,95$ & $5.23 \pm 2,53$ & $4,83^{*} \pm 2,28$ \\
\hline \multirow{2}{*}{ Lb. johnsonii $\mathrm{K} 4$} & 30 & $5,24 \pm 1,84$ & $5,53 \pm 1,74$ & $5,40 \pm 1,97$ \\
\hline & 37 & $5,50 \pm 2,22$ & $3,93^{*} \pm 2,03$ & $4,30^{*} \pm 2,06$ \\
\hline \multicolumn{2}{|c|}{ Próba kontrolna / Control sample } & $5,04 \pm 2,10$ & $5,16 \pm 2,12$ & $6,09 \pm 1,97$ \\
\hline \multicolumn{2}{|r|}{-} & $\mathrm{N}=50$ & $\mathrm{~N}=30$ & $\mathrm{~N}=53$ \\
\hline
\end{tabular}

Objaśnienia / Explanatory notes:

* - wartości średnie oznaczone gwiazdką są statystycznie istotnie różne od próby kontrolnej $(\mathrm{p}<0,05)$ / mean values denoted by asterisk differ statistically significantly from control sample $(\mathrm{p}<0.05)$.

Wpływ szczepu i zawartości sacharydów (8 i 10 \%) na pożądalność sensoryczną fermentowanego napoju miodowego oceniono w badaniu Łapińskiej [13]. Najwyżej 
oceniono napoje miodowe zawierające $10 \%$ sacharydów, fermentowane w temp. 32 i $37^{\circ} \mathrm{C}$ z udziałem szczepu $L b$. acidophilus $\mathrm{CH}-2$.

Wśród wyników badań dostępnych w literaturze, dotyczących zastosowania miodu i probiotyków, można zacytować badania Fiorda i wsp. [7]. Napój probiotyczny otrzymany przez ww. autorów na bazie hydrolizatu sojowego, siary bydlęcej, miodu oraz ziaren kefirowych i zawierający potencjalnie probiotyczne szczepy (Lb. statsumensis, Leuconostoc mesenteroides, Bacillus megaterium, Saccharomyces cerevisiae i Lachancea fermentati) wykazywał działanie ochronne DNA i właściwości antyoksydacyjne. Kantachote i wsp. [9] wyprodukowali napój funkcjonalny z tzw. mleka kokosowego $\mathrm{z}$ dodatkiem potencjalnie probiotycznego $L b$. plantarum DW12. Zwiększone korzyści zdrowotne napoju były związane $\mathrm{z}$ wytwarzaniem przez probiotyk kwasu $\gamma$-aminomasłowego (GABA), witaminy $\mathrm{B}_{12}$, przeciwutleniaczy i związków przeciwbakteryjnych. Dodatek miodu zwiększył akceptowalność sensoryczną napoju.

\section{Wnioski}

1. Potencjalnie probiotyczne bakterie przeżywały w napoju miodowym maksymalnie w liczbie $8,14 \log \mathrm{jtk} / \mathrm{cm}^{3}$. Zatem spełniły istotne kryterium technologiczne stawiane probiotykom.

2. W trzech wariantach fermentacja dłuższa niż 3 dni skutkowała zamieraniem komórek w produkcie.

3. Na podstawie prawidłowego przebiegu procesu fermentacji i korzystnej oceny sensorycznej produktu wskazane jest stosowanie do produkcji szczepu Lactobacillus casei $\mathrm{O} 12$ oraz prowadzenie fermentacji przez 2 dni w temp. $37^{\circ} \mathrm{C}$.

4. Istnieje konieczność doboru szczepu i warunków fermentacji innowacyjnego napoju o pożądanych cechach sensorycznych. Porcja ok. $100 \mathrm{ml}$ będzie dostarczać ok. 10 log jtk żywych potencjalnie probiotycznych mikroorganizmów. Na tym etapie badań produkt nie może być nazwany probiotycznym, jednak jakość sensoryczna i zakres przeżywalności szczepów predysponuje do dalszej oceny ich właściwości probiotycznych.

\section{Literatura}

[1] Aureli P.,Capurso L., Castellazzi A.M., Clerici M., Giovannini M., Morelli L. Poli A., Pregliasco F., Salvini F., Zuccotti G.V.: Probiotics and health: An evidence-based review. Pharmacol. Res., 2011, 63 (5), 366-376.

[2] Babicz-Zielińska E., Zabrocki R.: Postawy konsumentów wobec prozdrowotnej wartości żywności. Żywność. Nauka Technologia. Jakość, 2007, 6 (55), 81-89.

[3] Baryłko-Pikielna N., Matuszewska I.: Sensoryczne badania żywności. Podstawy. Metody. Zastosowania. Wyd. II. Wyd. Nauk. PTTŻ, Kraków 2014. 
[4] Dyrektywa Rady 2001/110/WE z dnia 20 grudnia 2001 r. odnosząca się do miodu. Dz. Urz. UE L 10, ss. 47-52, z 12.01.2002 z późn. zm.

[5] FAO/WHO: Guidelines for the Evaluation of Probiotics in Food. Raport of a Joint FAO/WHO Working Group on Drafting Guidelines for the Evaluation of Probiotics in Foods. London, Ontario, Canada, 2002.

[6] Farnworth E.R., Champagne C.P.: Production of probiotic cultures and their incorporation into foods. In: Probiotics, Prebiotics, and Synbiotics. Ed. R.R. Watson, V.R. Preedy. Academic Press, San Diego 2016, pp. 303-318.

[7] Fiorda F.A., de Melo Pereira G.V., Thomaz-Soccol V., Medeiros A.P., Rakshit S.K., Soccol C.R.: Development of kefir-based probiotic beverages with DNA protection and antioxidant activities using soybean hydrolyzed extract, colostrum and honey. LWT - Food Sci. Technol., 2016, 68, 690697.

[8] Holzapfel W.H., Schillinger U.: Introduction to pre- and probiotics. Food Res. Int., 2002, 35, 109116.

[9] Kantachote D., Ratanaburee A., Hayisama W., Sukhoom A., Nunkaew T.: The use of potential probiotic Lactobacillus plantarum DW12 for producing a novel functional beverage from mature coconut water. J. Funct. Foods, 2017, 32, 401-408.

[10] Klindt-Toldam S., Larsen S.K., Saaby L., Olsen L.R., Svenstrup G., Müllertz A., Knøchel S., Heimdal H., Nielsen D.S., Zielińska D.: Survival of Lactobacillus acidophilus NCFM® and Bifidobacterium lactis HN019 encapsulated in chocolate during in vitro simulated passage of the upper gastrointestinal tract. LWT - Food Sci. Technol., 2016, 74, 404-410.

[11] Kudełka W., Łobaza D.: Charakterystyka żywności funkcjonalnej. Zesz. Nauk. UE w Krakowie, 2007, 743, 91-120.

[12] Kun S., Rezessy-Szabó J.M., Nguyen Q.D., Hoschke Á.: Changes of microbial population and some components in carrot juice during fermentation with selected Bifidobacterium strains. Process Biochem., 2008, 43, 816-821.

[13] Łapińska E.: Wpływ wybranych czynników technologicznych na jakość mikrobiologiczną i sensoryczną fermentowanych napojów miodowych. Praca magisterska. SGGW, Warszawa 2013.

[14] Majewska E., Trzanek J.: Właściwości przeciwutleniające miodów wielokwiatowych i innych produktów pszczelich. Bromatol. Chem. Toksykol., 2009, XLII, 1089-1094.

[15] Marsh A.J., Hill C., Ross R.P., Cotter P.D.: Fermented beverages with health-promoting potential: Past and future perspectives. Trends Food Sci. Technol., 2014, 38, 113-124.

[16] Obiedzińska A., Waszkiewicz-Robak B.: Oleje tłoczone na zimno jako żywność funkcjonalna. Żywność. Nauka. Technologia. Jakość, 2012, 1 (80), 27-44.

[17] Ouwehand A.C.: A review of dose-responses of probiotics in human studies. Benef. Microbes, 2016, $8,143-151$.

[18] Szydłowska A., Kołożyn-Krajewska D.: Zastosowanie bakterii potencjalnie probiotycznych do fermentacji przecieru z dyni. Żywność. Nauka. Technologia. Jakość, 2010, 6 (73), 109-119.

[19] Zielińska D., Rzepkowska A., Radawska A., Zieliński K.: In vitro screening of selected probiotic properties of Lactobacillus strains isolated from traditional fermented cabbage and cucumber. Curr. Microbiol., 2014, 70, 183-194. 


\title{
SENSORY QUALITY AND VIABILITY OF POTENTIALLY PROBIOTIC STRAINS OF LACTOBACILLUS IN FERMENTED HONEY BEVERAGE
}

\begin{abstract}
S u m m a r y
The objective of the research study was to determine the possibility of using potentially probiotic strains of Lactobacillus johnsonii $\mathrm{K} 4$ and Lactobacillus casei $\mathrm{O} 12$ to manufacture a honey beverage having a appropriate sensory quality and containing viable microorganisms. The research material consisted of honey beverages made of multifloral honey and tap water $(12.05 \mathrm{~g} / 100 \mathrm{ml})$. The beverages were fermented for 2, 3, 4 and 5 days with a bacterial monoculture (after inoculation of approx. $7 \mathrm{log} \mathrm{cfu} / \mathrm{ml}$ ) at a temperature of 30 and $37^{\circ} \mathrm{C}$. The average count of bacteria ranged from 6.75 to $8.14 \mathrm{log} \mathrm{cfu} / \mathrm{ml}$. The growth of bacteria depended on the strain, the time and the temperature of fermentation $(p<0.05)$. The same factors significantly impacted the mean $\mathrm{pH}$ values of all the samples on the subsequent days of fermentation; those $\mathrm{pH}$ values ranged between 4.6 and $4.8(\mathrm{p}<0.05)$. The fermentation time was a factor to statistically significantly impact the sensory evaluation $(\mathrm{p}<0.05)$. The samples fermented with a $\mathrm{Lb}$. casei $\mathrm{O} 12$ strain for 2 days at $37^{\circ} \mathrm{C}$ were given the highest scores in the sensory evaluation. The selected bacteria of the Lactobacillus species can be used to manufacture an innovative beverage having desirable sensory qualities. At this stage of the research, the product cannot be called probiotic; however, the sensory quality and the range of viability of the strains predispose them to continue evaluation of their probiotic properties.
\end{abstract}

Key words: honey beverage, probiotic, fermentation, Lactobacillus 